\title{
ARTIKEL
}

\section{Technische beroepen in transitie}

\author{
Maren Boersma, Wouter van der Torre, Jolanda Janssen \& Jos Sanders*
}

Nieuwe geavanceerde technologieën, zoals Internet of Things (IoT), robotisering, nanotechnologie en 3D-printtechnieken, doen in steeds sterkere mate hun intrede in de industrie. De verwachting is dat technische beroepen daardoor aanzienlijk gaan veranderen en dat vraagt ook om andere competenties (kennis, vaardigheden en gedrag). Er ligt een belangrijke taak voor bedrijven, sociale partners, onderwijsinstellingen en werknemers om die veranderingen goed en gestructureerd in kaart te brengen, zodat opleidings- en ontwikkelingsinspanningen van huidig en toekomstig technisch personeel kunnen worden gericht op de taken van de (nabije) toekomst. Dit artikel beschrijft de resultaten van een verkenning van wetenschappelijke studies naar de impact van technologische ontwikkelingen op de arbeidsinhoud en de daaruit voortvloeiende competentiebehoeften bij technisch personeel. De belangrijkste conclusie is dat er in de wetenschappelijke literatuur nog weinig aandacht is voor veranderingen in de arbeidsinhoud en bijbehorende competentiebehoefte als gevolg van technologische ontwikkelingen. Vanwege dat beperkte aantal relevante wetenschappelijke artikelen is de studie aangevuld met artikelen uit de grijze literatuur en inzichten uit een achttal praktijkvoorbeelden. Deze studie laat onder meer zien dat technologische ontwikkelingen ertoe leiden dat bediening van geavanceerde robots, programmeren, oplossen van storingen en het onderhouden en ontwerpen van producten belangrijke(re) taken worden die ook om nieuwe competenties vragen.

\section{Inleiding}

Digitalisering, robotisering en automatisering en de gevolgen hiervan staan volop in de schijnwerper. Brynjolfsson en McAfee (2014) stellen daarbij computertechnologie in combinatie met netwerktechnologie centraal. Dit wordt beschouwd als 'general purpose technology', dat wil zeggen: een technologie met een brede 'cross-cutting' potentie die op veel mensen en verschillende aspecten van economie en maatschappij een grote invloed kunnen hebben met een breed palet aan mogelijke nieuwe toepassingen. In Europa wordt sterk gefocust en gestuurd op brede uitrol van de zogenaamde Key Enabling Technologies (KETs), waaronder nanotechnologie, industriële biotechnologie, fotonica, micro- en nano-elektronica,

* Maren Boersma en Wouter van der Torre zijn werkzaam bij TNO. Jos Sanders is werkzaam bij de Hogeschool Arnhem en Nijmegen (HAN), kenniscentrum kwaliteit van leren. Jolanda Janssen is werkzaam bij Opleiding Ontwikkeling Metaalbewerking $(\mathrm{OOM})$. E-mail: wouter.vandertorre@tno.nl. Dit artikel is tot stand gekomen in samenwerking met de technische fondsen A+O Metalektro, OOM, OOMT, OOC, OTIB, OVP en OOI. 
nieuwe materialen en nieuwe productiemethoden. De impact van deze nieuwe technologieën op de arbeidsmarkt staat daarmee ook volop in de belangstelling. Belangrijke aanleiding voor deze (internationale) belangstelling zijn onder andere publicaties van Frey en Osborne (2013) over de impact van nieuwe technologie op de werkgelegenheid. Ook in Nederland zijn verschillende onderzoeken uitgevoerd met betrekking tot dit thema, waaronder die van Deloitte (2014), het Rathenau Instituut (Van Est \& Kool, 2015), het CPB (2015), de WRR (2015) en de SER (2016). Over het algemeen is de boodschap van deze studies dat de intrede van nieuwe technologieën leidt tot substantiële veranderingen in de structuur van de werkgelegenheid op de Nederlandse arbeidsmarkt. Dit zijn veranderingen met grote gevolgen voor verschillende groepen werknemers. Over wat die veranderingen precies zijn en hoe werknemers en werkgevers zich daar goed op kunnen voorbereiden, lopen de verwachtingen echter sterk uiteen.

Frey en Osborne (2013) en Deloitte (2014) waarschuwen dat veel banen grotendeels zouden kunnen worden geautomatiseerd waardoor in de komende twee decennia veel banen zullen verdwijnen. In deze studies is echter geen rekening gehouden met het ontstaan van nieuwe taken en banen en er wordt vooral geredeneerd vanuit technologische mogelijkheden (en bijvoorbeeld niet vanuit wat organisaties wenselijk achten). De OECD (Arntz, Gregory, \& Zierahn, 2016) heeft recenter een vergelijkbare analyse gedaan, waarbij naar taken is gekeken in plaats van banen en waarbij onder meer rekening is gehouden met het ontstaan van nieuwe taken. Op basis daarvan concludeert de OECD een veel beperktere impact op de totale werkgelegenheid. Voor de OECD-landen samen is sprake van automatiseerbaarheid van ongeveer $9 \%$ van de werkgelegenheid. In Nederland is dat $10 \%$. De tijdshorizon waarop de (mogelijke) krimp plaatsvindt, is moeilijk in te schatten voor de onderzoekers. Frey en Osborne (2013) verwachten dat het over een periode van grofweg twee decennia kan plaatsvinden en Deloitte en de OECD gebruiken die studie als referentie. De OECD verwacht daarbij dat vooral de banen van middelbaar en laagopgeleiden onder druk staan. Onderzoek van het CPB (2015) bevestigt dat het aandeel beroepen op middelbaar niveau de afgelopen jaren inderdaad is afgenomen en dat de werkloosheid onder middelbaar opgeleiden ook is gestegen. Onderzoek van Goos, Manning en Salomons (2014) laat daarentegen zien dat het aandeel banen op laag niveau de laatste jaren nog is toegenomen. Dit zijn echter allemaal bevindingen die 'slechts' een algemene indruk geven van recente verschuivingen in de structuur van de vraag naar arbeid op de Nederlandse arbeidsmarkt. Die bevindingen zijn zo algemeen dat het moeilijk is voor werknemers en werkgevers om er daadwerkelijk op te acteren, bijvoorbeeld door gerichte bij- of omscholing van krimp- naar groeisegmenten, en om in dat kader gerichte keuzes te maken in het kader van leven lang leren. Meer en gedetailleerde informatie over de impact van technologische ontwikkelingen op de aard en inhoud van het huidige werk, op taakniveau, is nodig om scherp in beeld te krijgen wat de verschuivingen in de werkgelegenheidsstructuur precies behelzen en welke verschuivingen juist in de technische beroepen zichtbaar zijn.

Op het niveau van arbeidsinhoud en veranderingen in taken is echter nog maar zeer beperkt onderzoek gedaan. Van den Berge en Ter Weel (2015) laten, zij het ook op een vrij hoog en abstract niveau, zien dat vanaf 1996 het aandeel routinematige fysieke en cognitieve taken is afgenomen en het aandeel non-routine- 
matige analytische en interactieve taken is toegenomen. Zij koppelen deze verschuivingen ook aan de verschuivingen in de structuur van de werkgelegenheid. Routinematige fysieke taken (zoals eenvoudige assemblage) en cognitieve taken (zoals boekhouden) zijn makkelijker te automatiseren. Dat zijn taken die vooral door middelbaar opgeleiden werden uitgevoerd. Laagopgeleiden hebben te maken met routinematige taken, maar er zijn ook veel interactieve taken (zoals klantcontacten) aan de onderkant van de arbeidsmarkt en daar zit juist groei in.

Uit vergelijkbaar onderzoek in de Verenigde Staten waarin verder in de tijd wordt teruggekeken (Levy \& Murnane, 2013) blijkt dat routinematige handmatige en routinematige cognitieve en non-routinematige handmatige taken ook op langere termijn in belang afnemen. Daarentegen worden het 'oplossen van ongestructureerde problemen' en 'werken met nieuwe informatie' sinds 1960 belangrijker (Levy \& Murnane, 2013). De verwachting is dan ook dat de ontwikkeling naar minder routinematige en meer complexe taken zich wereldwijd doorzet. Deze ontwikkelingen verklaren (deels) ook de polarisatie op de arbeidsmarkt.

Daarbij lijkt het noodzakelijk om onderscheid te maken tussen verschillende sectoren. Welke toegepaste technologieën belangrijk zijn en wat de specifieke impact is van deze technologieën, verschilt namelijk per sector (SER, 2016; Oeij, Van der Torre, Van de Ven, Sanders, \& Van der Zee, 2016; Rabobank, 2016). Ook de mate van polarisatie in de arbeidsmarkt verschilt per sector. In het recente verleden is er bijvoorbeeld met name sprake van polarisatie in de commerciële dienstverlening en de industrie (Smits \& De Vries, 2015). Daarom is het van belang dat sectoraal geanalyseerd wordt wat de gevolgen zijn van nieuwe technologieën voor taken en competentiebehoeften. Met behulp van deze kennis kunnen werkgevers en werknemers zich optimaal voorbereiden, zodat ze kunnen profiteren van de kansen en rekening kunnen houden met de bedreigingen van nieuwe technologie. Een van de sectoren waar dit vraagstuk erg relevant is gezien de snelle technologische ontwikkelingen, is de industrie.

Het doel van dit artikel is om inzicht te geven in de gevolgen van nieuwe technologieën op de arbeidsinhoud en de daaraan gerelateerde behoefte aan (nieuwe) competenties voor werknemers in technische beroepen in de industrie. De volgende onderzoeksvraag staat centraal: welke kennis is er over de impact van relevante technologische ontwikkelingen op de arbeidsinhoud en de daaraan gerelateerde competentiebehoefte in technische beroepen in de industrie?

\section{Methoden}

Dit artikel is gebaseerd op een literatuuronderzoek aangevuld met casestudies. Voor het literatuuronderzoek is gezocht naar internationale en nationale wetenschappelijke literatuur en 'grijze literatuur' met behulp van Scopus en Google Scholar.

Om tot een goed overzicht te komen van relevante zoektermen hebben we allereerst in overleg met experts uit de sector de meest relevante nieuwe technologieën voor technische beroepen geïnventariseerd. De volgende zoektermen zijn in het literatuuronderzoek gebruikt: augmented reality, production technologies, virtual reality, advanced manufacturing systems, robots, robotics, additive 
manufacturing, rapid prototyping, cyber physical systems, Internet of Things, cloud-based manufacturing, 3d printing, workplace innovation, innovation, nanotechnology, industry 4.0 en smart industry.

Omdat we expliciet zoeken naar veranderingen voor technische beroepen en in technische functies, hebben we gezocht naar literatuur waarin het gaat over nieuwe technologieën in relatie tot industriesectoren. We hebben daarbij zowel zoektermen gebruikt die verwijzen naar industriële productie (manufacturing, industry, production, assembly, logistics, order picking, engineering, mechanical engineering, manufacturing engineering) als zoektermen voor specifieke technische sectoren (automotive, iron, steel, metal, shipbuilding, construction, transportation, cycling, aircraft, aerospace, polymer, beverage, oil, chemical, pharmaceutical, plastic, rubber, food, electronic, automotive repair, plastics packaging, thermal insulation, installation technology en food process).

Vervolgens zijn met experts van acht technische scholingsfondsen de relevante zoektermen benoemd waarmee we artikelen zouden kunnen vinden waarin zowel aandacht is voor de impact van deze nieuwe technologieën op de arbeidsinhoud als voor de daaraan gerelateerde (nieuwe) competentiebehoefte bij technisch personeel in de industrie of die specifieke industriesectoren. De volgende zoektermen zijn uiteindelijk gebruikt in combinatie met de eerdergenoemde zoektermen voor nieuwe technologieën en technische sectoren: skills, competences, work processes, tasks, training, education, decision making, creativity, entrepeneurship, knowledge en cooperation. Naast de Engelse zoektermen zijn ook Nederlandse zoektermen gebruikt. Dit betrof dan de vertaling van de Engelse zoekterm.

De zoekopdracht in Scopus leverde 35 artikelen op, waarvan er slechts één echt bruikbaar was in de zin dat het artikel ook ging over technologische ontwikkeling in de industrie én de impact van die ontwikkeling op de veranderende arbeidsinhoud én de in relatie daarmee gevraagde competenties. Daarna is gezocht in Google Scholar. Ook hier bleek niet veel te zijn gepubliceerd over de impact van nieuwe technologieën op veranderingen in arbeidsinhoud en daaraan gerelateerde (nieuwe) competentiebehoeften in de technische beroepen. Hierbij moet worden opgemerkt dat de 'grijze' literatuur moeilijker (systematisch) te ontsluiten is. Het is daarom lastig aan te geven in hoeverre hierin veel geschreven is over de impact van nieuwe technologie op competentiebehoeften in de technische beroepen. Wat betreft deelsectoren zijn er voor de technische installatiebranche en elektrotechnische sector specifieke rapporten gevonden. Verder richt de literatuur zich op industriële productie in het algemeen en niet op deelsectoren, zoals bijvoorbeeld metaal, carrosseriebouw of procesindustrie. Uiteindelijk leverden de zoekopdrachten dertien bruikbare publicaties op waaronder rapporten, papers gepresenteerd op internationale conferenties en slechts twee peer-reviewede artikelen. Het zijn veelal publicaties gebaseerd op casestudies en expertoordelen (experts uit de praktijk en technologie-experts). Met uitzondering van één bron zijn alle gebruikte bronnen gepubliceerd tussen 2013 en 2016. Het merendeel van de publicaties richtte zich op robotisering en co-botisering al dan niet gecombineerd met IoT. De aandacht voor de impact van 3D-printen en nanotechnologie op arbeidsinhoud en competenties was veel beperkter. Daarnaast had een aantal artikelen een sectorspecifieke insteek, zoals de elektrotechnische sector in België. 
In aanvulling op het literatuuronderzoek zijn acht praktijkvoorbeelden onderzocht om de veranderende taken en competentiebehoeften te illustreren. Per cluster van technologieën zijn concrete voorbeelden van bedrijven in de industriële sector beschreven, waar geëxperimenteerd of gewerkt wordt met nieuwe technologieën. Deze verkenning van praktijkvoorbeelden is een weergave van reeds beschikbare en gedocumenteerde kennis en informatie over zowel technologische ontwikkelingen als de impact ervan op arbeidsinhoud, daaruit voortvloeiende competentiebehoeften en manieren om werknemers te voorzien van die competenties. Beschrijvingen zijn gebaseerd op publicaties in tijdschriften, nieuwsbrieven en op websites. De cases zijn geïnventariseerd en geselecteerd op basis van het netwerk en de expertise van de auteurs en experts uit het technische sectoren. Voor ontwikkelingen op het gebied van nanotechnologie en nieuwe materialen bleek een dergelijke praktijkbeschrijving nog niet beschikbaar. Om die reden is voor dit cluster van technologische ontwikkelingen geen concreet voorbeeld uit de praktijk opgenomen.

\section{Resultaten}

Hieronder beschrijven we in een viertal clusters van technologische ontwikkelingen de belangrijkste bevindingen van het literatuur- en praktijkonderzoek. De clustering van technologische ontwikkelingen is mede ingegeven door de resultaten van de literatuurstudie. Alleen de technologische ontwikkelingen waarvoor bruikbare publicaties zijn gevonden, komen daarbij aan bod. We gaan in deze resultatensectie eerst kort in op de technologische ontwikkeling zelf en vervolgens beschrijven we de implicaties ervan voor arbeidsinhoud en competentiebehoeften bij werknemers in technische beroepen in de industrie. We sluiten af met een concreet voorbeeld uit de casestudies.

\section{Robotisering en co-botisering}

Robots en co-bots (collaborative robots) worden geavanceerder en spelen een steeds grotere rol in de industrie. De verwachting is dat het aantal robots in de industrie wereldwijd met ongeveer $15 \%$ per jaar zal toenemen tot 2020, met de sterkste groei in Azië en de VS (IFR, 2017). Taken die uitgevoerd kunnen worden door robots, zijn onder meer boren, lassen en verspanen, maar ook assembleren, tillen of metingen verrichten. Robots kunnen worden ingezet ten behoeve van een versnelling van het productieproces en het verminderen van de foutenmarge (t.b.v. reproduceerbaarheid en kostenbesparing); ook kunnen zij ingezet worden om taken uit te voeren die mensen niet kunnen uitvoeren of om het werk voor mensen lichter maken (minder fysieke belasting). Daarnaast kunnen sommige robots werken op plaatsen en in omgevingen die niet toegankelijk zijn voor mensen (Bezemer \& Smit, 2017). Met het inzetten van co-bots is er bovendien sprake van een (veilige en effectieve) samenwerking tussen mens en robot, waarbij co-bots veelal ingezet worden voor ondersteunende taken die een mens niet kan uitvoeren of minder nauwkeurig kan uitvoeren, zoals laserbots die zeer nauwkeurig metaal kunnen snijden (Moniz \& Krings, 2016). 
Implicaties voor arbeidsinhoud en competentiebehoeften

Met de inzet van robots verandert het productieproces. Voor sommige taken of processen geldt dat ze volledig door robots overgenomen kunnen worden. Hierbij kunnen functies gedeeltelijk of geheel verdwijnen. Tegelijkertijd kan de inzet van robots en co-bots leiden tot een verandering van takenpakketten van werknemers (verdeling van het werk tussen mens en robot) en ontstaan er nieuwe taken (Oeij et al., 2016).

Het overnemen van taken en processen door robots heeft vooral gevolgen voor werknemers die simpele, repetitieve taken uitvoeren (Moniz \& Krings, 2016). Wanneer robots deze simpele en repetitieve taken overnemen, kunnen werknemers bijvoorbeeld meer controlerende taken krijgen, zoals toezicht houden op het productieproces (Moniz \& Krings, 2016). Voor deze 'operators' geldt dan dat zij nieuwe basisvaardigheden moeten leren voor de bediening van robots en het registreren van storingen aan robots, en dat zij moeten leren toezicht te houden op door robots uitgevoerde productieprocessen (Moniz \& Krings, 2016). Ook hebben deze operators enig basisinzicht nodig in wetgeving op het gebied van arbo en veiligheid, ergonomie en het herkennen en voorkomen van (potentieel) gevaarlijke situaties (Gijsbers, Van den Broek, Esmeijer, \& Sanders, 2016). Dergelijke inzichten zouden zij kunnen opdoen in zowel het regulier bekostigd onderwijs als in aanvullende opleidingen en trainingen. Omdat genoemde wetgeving echter aan verandering onderhevig is, wordt hier ook een blijvende investering gevraagd van werknemers en werkgevers, zodat operators zich ook hun leven lang kunnen blijven ontwikkelen.

Met de inzet van robots die taken nauwkeuriger kunnen uitvoeren dan mensen (bijvoorbeeld lassen, snijden of het buigen van metaal), wordt de assemblage meer gekenmerkt als een 'plug-and-play'-proces. Ook deze vernieuwing vraagt aanpassingen bij de huidige populatie van productiemedewerkers. Zij zullen in mindere mate te maken krijgen met het handmatig behandelen van materiaal (Bezemer \& Smit, 2017). Daarentegen wordt kennis van het productieproces, machines en softwarematige besturing belangrijker en worden logistieke handelingen voor het op- en afspannen van materialen van groter belang (Bezemer \& Smit, 2017). Ook is er met de komst van robots een groeiende behoefte aan personeel dat goed kan werken met CAD/CAM (computer-aided design/computeraided manufacturing) software (Gijsbers et al., 2016), die wordt gebruikt om producten te ontwerpen en productieprocessen in te richten. Daarmee lijkt het van belang dat de huidige populatie productiemedewerkers op een hoger kennisniveau komt wat betreft de werking van nieuwe machines, de programmering van robots, kwaliteitscontrole en onderhoudstaken. Voor medewerkers die werken met lasrobots, betekent dit dat zij technische kennis moeten hebben van het lassen met lasrobots en dat zij moeten beschikken over (computer)vaardigheden met betrekking tot software en datamanagement (Folmer, 2013; Bezemer \& Smit, 2017).

\section{Voorbeelden uit de praktijk}

Uit een voorbeeld van de automatisering van carrosseriebouw (namelijk laswerkzaamheden bij een fabrikant van bussen) (Oeij et al., 2017) blijkt dat deels vergelijkbare en deels andere skills nodig zijn nadat delen van het productieproces geautomatiseerd zijn of semiautomatisch zijn ingericht. Er is bijvoorbeeld nieuwe 
lasapparatuur dat de benodigde parameters automatisch instelt. Het daadwerkelijk instellen van de lasapparatuur hoeft een lasser niet meer te doen. De lasser heeft echter nog steeds kennis over lastechnieken nodig om na te kunnen gaan of de lasapparatuur goed ingesteld is. Apparatuur die instellingen automatisch regelt, verandert niets aan het van de lasser gevraagde opleidingsniveau. Iets soortgelijks speelt voor het bedrijf Hapert aanhangwagens, waar sinds 2013 gewerkt wordt met een lasrobot (Van Dijk, persoonlijke communicatie, 20 december 2017). Bij Hapert is het aantal medewerkers met de functie handlasser afgenomen: deze handlassers hadden met name kennis van lassen en lastechnieken en waren in het bezit van lasdiploma's. Medewerkers die nu werken met de lasrobots, zijn onder andere verantwoordelijk voor het omstellen van de mal en het inleggen van materialen. Van deze medewerkers wordt verwacht dat zij kennis hebben van lasprocessen, storingen, programmeren van lasrobots, en dat zij meedenken met het productie- en logistieke proces.

$\mathrm{Bij}$ het gebruik van lasrobots kunnen ook twee verschillende functies ontstaan: de operator van de robot en de programmeur van de robot (Oeij et al., 2017). Niet-geschoolde lassers kunnen veel taken uitvoeren (opspannen, eruit halen en dergelijke). Dit worden de operators, in feite lager geschoold werk (downgrading) waarvoor geen specifieke kennis van lastechnieken meer nodig is. Aan de andere kant zijn ook programmeervaardigheden nodig bij het volledig automatiseren van laswerkzaamheden. Er is iemand nodig die de lasrobot kan programmeren, waarvoor kennis van zowel lastechnieken als programmeren nodig is. Dit kan een nieuwe functie van 'lasprogrammeur' worden. Werknemers die nu lasser zijn, moeten er wel voor openstaan om deze nieuwe vaardigheden te leren. In totaal zijn er minder mensen per stap nodig om dezelfde, of zelfs meer, output te leveren. Echter, mede doordat de prijs/kwaliteitverhouding van de eindproducten is verbeterd door de automatisering en doordat de markt is aangetrokken, is de werkgelegenheid overigens niet afgenomen bij deze fabrikant (Oeij et al., 2016).

Internet of Things (IoT) en cyber-physical systems

IoT verwijst naar de interactie tussen objecten, apparaten, voertuigen, sensoren en controlesystemen die met elkaar verbonden zijn via een informatienetwerk (internet). IoT omvat hiermee (potentieel) intelligente en zelfsturende processen (Dworschak, Zaiser, \& Achtenhagen, 2013). Verwacht wordt dat het gebruik van IoT blijft toenemen. Dit betekent dat industriële processen verder geautomatiseerd kunnen worden (Dworschak \& Zaiser, 2014). IoT speelt ook een rol bij de installatie van domotica in fabrieken, woningen en andere gebouwen (Vermeulen et al., 2014). Hierbij gaat het specifiek om de integratie van hardware met software (cyber-physical systems). Denk bijvoorbeeld aan een verwarming die zichzelf aan of uitschakelt, automatische bevoorrading of het automatisch melden van brand of een inbraak naar de bewakingscentrale of politie.

Implicaties voor arbeidsinhoud en competentiebehoeften

Wat betreft industriële productie wordt verwacht dat laaggeschoolde banen en simpele repetitieve taken vervangen worden door intelligente zelfsturende systemen (Kinkel et al., 2008 in Hirsch-Kreinsen, 2014). Hierbij gaat het bijvoorbeeld om eenvoudige logistieke taken, de bediening van machines of de invoer van 
data. Een mogelijk gevolg is dat een deel van het laaggeschoold werk verdwijnt, maar de mate waarin dit daadwerkelijk zal gebeuren, is moeilijk in te schatten. Een achterblijvende groep productiemedewerkers houdt zich bijvoorbeeld bezig met onderhoudstaken, voorbereidend werk of de invoer van materialen of halffabricaten in het productieproces: taken die moeilijk, of enkel tegen hoge kosten, geautomatiseerd kunnen worden (Hirsch-Kreinsen, 2014).

Een concrete verandering in industriële productie is dat foutenregistratie in productieprocessen in de toekomst wordt overgenomen door machines en objecten verbonden via het IoT. Controlesystemen worden complexer: de communicatie tussen machines wordt ondoorzichtig of zelfs ontoegankelijk en kan ook over grote afstand plaatsvinden (Dworschak \& Zaiser, 2014). Dit kan een verschuiving van werkzaamheden met zich meebrengen. Voor controlepersoneel geldt bijvoorbeeld dat ze niet langer foutmeldingen hoeven te interpreteren, maar enkel aangeleverde instructies uitvoeren (bijvoorbeeld via een scherm), informatie beoordelen en hier adequaat naar handelen (Achtenhagen \& Zeller, 2013). De integratie van systemen en netwerken maakt het daarbij tevens mogelijk om op afstand een diagnose te stellen en hiernaar te handelen (Abelshausen, Albertijn, \& Hoefnagels, 2014). In geavanceerde zelfsturende systemen is het daarbij van belang dat daartoe gekwalificeerd personeel ${ }^{1}$ probleemoplossende systemen en communicatiekanalen goed op elkaar afstemt. Daarbij wordt aangegeven dat het personeel in staat moet zijn om zelfstandig kennis te verkrijgen van nieuwe technologie en softwaresystemen die zich snel ontwikkelen en die hierbij een rol spelen (Dworschak \& Zaiser, 2014).

Voor machine-operators geldt dat het routinematig monitoren van machines door middel van visuele inspecties en statusberichten op computerschermen mogelijk wordt vervangen door het monitoren van signalen afgegeven door machines en/of computers (Achterhagen \& Zeller, 2013). Op deze signalen dient (snel) gereageerd te worden, bijvoorbeeld door assistentie te verlenen bij de machine of monitor. Operators worden verantwoordelijk voor een hele (geautomatiseerde) productiestraat in plaats van één of enkele machines. Hiervoor zijn vaardigheden als systematisch analyseren en probleemoplossend vermogen van belang (ING Economisch Bureau, 2016). Routinematig werk en repetitieve handelingen worden geautomatiseerd en er ontstaan taken op het gebied van probleemanalyse en storingsanalyse. Voor onderhoudstechnici geldt dat de nadruk meer komt te liggen op interpretatie van data en gebruik van ICT.

Wat betreft veranderingen in onderhoudstaken als gevolg van het IoT, zijn verschillende opvattingen in de literatuur te vinden. Achtenhagen en Zeller (2013) verwachten dat met zelf-monitorende systemen en sensoren die de onderhoudsbehoefte kunnen registreren, onderhoud aan machines meer zal gebeuren op afroepbasis. Tegelijkertijd verwachten De Vos en Gielens (2016) dat in de chemische en levensmiddelenindustrie een verschuiving van onderhoud op afroep (bijvoorbeeld bij een defect of vastgelopen machine) naar preventief en 'predictief' onderhoud (waarbij met behulp van metingen de staat van machines en installaties gecontroleerd kan worden, zodat onderhoud tijdig wordt ingepland). Dit betekent dat het belangrijk wordt dat onderhoudstechnici interventies opvolgen, maar ook dat zij proactief kunnen handelen en vooruitdenken (De Vos \& Gielens, 2016). Skevi et al. (2014) suggereren een nieuwe functie van 'quality technicians', 
die verantwoordelijk zijn voor de planning en preventief onderhoud van apparaten en instrumenten.

Wat betreft kennis en vaardigheden zal er vraag zijn naar diepere kennis van informatietechnologie, elektronica, mechanische systemen en snelle informatieverwerking in het geval van een storing (Hirsch-Kreinsen, 2014; Corporaal, Alons, \& Vos, 2015). Om onderhoud uit te voeren aan netwerksystemen moeten werknemers beschikken over kennis en vaardigheden voor het werken met elektromechanische apparatuur, informatienetwerken, sensoren, radio's en andere transmissietechnologieën (Achtenhagen \& Zeller, 2013; Dworschak \& Zaiser, 2014). Denk hierbij bijvoorbeeld aan radio-frequency identification (RFID), ofwel identificatie met radiogolven: een technologie om van een afstand informatie op te slaan met behulp van zogenaamde RFID-tags (die zitten bijvoorbeeld op objecten, ov-chipkaarten of op levende wezens) (Achtenhagen \& Zeller, 2013). Meer medewerkers hebben een brede, technische opleiding nodig. In combinatie met een opleidingsprogramma waarin ze alle fasen van het productieproces doorlopen, kunnen medewerkers dan in het hele productieproces worden ingezet (Gijsbers et al., 2016).

Vergaande automatisering van industriële processen via IoT-systemen vraagt verder om andere werkzaamheden aan de voorkant en het einde van het productieproces. Het betreft hier een verrijking van werkzaamheden (upgrading). Wat betreft technische vaardigheden voor hooggeschoold personeel zijn parametriseren, plannen en programmeren met behulp van speciale software belangrijke vereisten bij het werken met IoT-systemen. Toekomstige engineers zullen meer tekstueel werken, in programmeertaal als SCL. Hiervoor moeten ze met software werken waarin ze in één gemeenschappelijke engineeromgeving alle disciplines kunnen programmeren (Marks \& Penris, 2013).

Hooggeschoold personeel moet ook in staat zijn om met verschillende experts te communiceren - in real-time en over afstand - over deze complexe productieprocessen. Dit vraagt interdisciplinaire vaardigheden. Onafhankelijk handelen en effectief communiceren over abstracte problemen worden ook van belang. Het productieproces en de controle en het onderhoud hiervan worden complexer; hooggeschoold personeel moet overzicht kunnen houden en kunnen omgaan met deze grote mate van complexiteit (Achtenhangen \& Zeller, 2013; HirschKreinsen, 2014). Ook moet er voldoende kennis zijn van het proces, productieprocedures en de waardeketen, zodat de juiste aanpassingen en interventies kunnen worden toegepast. Er kunnen 'specialist engineers' worden opgeleid, die programmeerkennis hebben en complexe productiesystemen kunnen reguleren en onderhouden (Hirsch-Kreinsen, 2014).

\section{Voorbeelden uit de praktijk}

Een concrete toepassing van IoT is te vinden in verkeersborden van de HR Groep (KPN, 2017). Hierbij worden sensoren bevestigd aan verkeersborden en wordt op een energiezuinige manier over lange afstand informatie verstuurd via een hiervoor specifiek ingericht netwerk (KPN, 2017). De sensoren kunnen aangeven of het bord gedraaid is of dat dit niet meer rechtop staat, en ze kunnen eens per maand aangeven of de sensor nog werkt. Hierdoor kan een actueel inzicht worden verkregen van de status van alle borden. Dit wordt via een digitale plattegrond inzichtelijk gemaakt. Daarnaast kunnen de sensoren aan verkeers- 
borden verbinding maken met 'in-car' systemen. Op deze manier worden verkeersborden direct zichtbaar gemaakt in navigatiesystemen (KPN, 2017). Wat betreft competenties vraagt dit van medewerkers die verkeersborden controleren dat zij de gegevens die sensoren doorsturen, moeten kunnen aflezen en hierop moeten kunnen handelen. Ook is het van belang dat er medewerkers zijn die sensoren kunnen plaatsen en onderhoud aan sensoren kunnen uitvoeren.

\section{D-printen / 'additive manufacturing'}

3D-printen is een productietechniek waarbij materialen worden toegevoegd in plaats van weggehaald. Met behulp van 3D-printen kunnen driedimensionale producten worden gefabriceerd. 3D-printers bouwen producten laag voor laag op. Dit proces is computergestuurd en gebeurt op basis van een CAD-tekening. 3D-printing kan worden ingezet voor specifieke doeleinden, zoals het personaliseren van producten. Denk bijvoorbeeld aan esthetische toevoegingen, maar ook het leveren van maatwerkproducten voor installatie of montage (of producten die bijvoorbeeld niet meer leverbaar zijn) (Bezemer, Kuindersma, \& Mulder, 2016). In de installatiebranche wordt 3D-printing routinematig toegepast voor het maken van zichtmodellen en prototypes (Bezemer et al., 2016).

\section{Implicaties voor arbeidsinhoud en competentiebehoeften}

Afhankelijk van hoe een 3D-printer gebruikt wordt, zijn verschillende vaardigheden en kennis nodig. Voor bedrijven die werken met applicaties en producten die al uitgewerkt en ontwikkeld zijn, is het bestellen/produceren van een onderdeel een routinematige handeling. Als een product nog helemaal ontwikkeld moet worden, materiaal en proceskeuze moeten worden gemaakt en producten in 3D-CAD ontwikkeld moeten worden, zijn diepgaande engineeringsvaardigheden en programmeervaardigheden noodzakelijk (Bezemer et al., 2016; Gijsbers et al., 2016).

Het wordt aangeraden om technisch-inhoudelijke kennis te centraliseren en te borgen. Het gaat hier om kennis met betrekking tot mogelijkheden van 3Dprinten, printtechnieken, materiaalkennis en mogelijkheden om 3D-scanning en 3D-printing te combineren. Daarnaast is er ook behoefte aan een proces-integrator of system engineer die sterke sociale competenties heeft omdat hij in zijn werk met meerdere partijen (ketenpartners) moet overleggen/afstemmen (Bezemer et al., 2016).

In de metaalbewerking en specifiek de fijnmechanische techniek zal het gebruik van 3D-printers en 3D-technieken naar verwachting toenemen (Folmer, 2013). Dit vereist dat medewerkers zelfstandig kunnen (CNC-)programmeren in combinatie met 3D-ontwerp. Hierbij is tekeninglezen ook een belangrijke competentie. Productiemedewerkers moeten tekeningen juist interpreteren en controleren op bijvoorbeeld maatvoering, vorm en plaats, tolerantie en maakbaarheid, voordat tot productie wordt overgegaan (Folmer, 2013; Cörvers, Hoon, \& Van den Tillaart, 2017).

\section{Voorbeelden uit de praktijk}

Een praktijkvoorbeeld komt van bedrijf Kaak Group (industriële bakkerijtechnologie), die gebruik maakt van 3D-metaalprinters waarmee ze verschillende onderdelen voor hun broodbaklijnen kunnen printen (A+O Metalektro, 2017). 
Hierbij worden metaalkorrels met behulp van een laser aan elkaar gesmolten. De opslagcapaciteit van metaalpoeder is dermate groot dat de printer gedurende 120 uur aaneengesloten kan printen. Nieuwe printopdrachten kunnen op afstand worden gegeven. Gevolg is dat er bij Kaak Group nieuwe functies bij gekomen zijn. Software engineers worden bijvoorbeeld ingezet voor de inbedrijfstelling van robottoepassingen, waarbij gewerkt moet kunnen worden met verschillende softwareprogramma's op het gebied van programmeren en $2 \mathrm{D} / 3 \mathrm{D}$-visualisatie. Daarnaast is er behoefte aan personeel met bijvoorbeeld een achtergrond in werktuigbouwkunde of mechatronica, dat in staat is om verschillende onderdelen van bakproductielijnen te ontwerpen in 3D (A+O Metalektro, 2017).

\section{Nanotechnologie / nieuwe materialen}

Nanotechnologie is de technologie die het mogelijk maakt om met deeltjes ter grootte van nanometers (een miljoenste deel van een millimeter) producten te ontwikkelen. Nanotechnologie maakt het bijvoorbeeld mogelijk om nieuwe materialen te ontwikkelen. Nanotechnologie is breed toepasbaar, zoals bij het produceren van emulsies (bijvoorbeeld voor zonnebrand of cosmetica), titaniumoxide in verf en vernis, elektrotechnische applicaties en metaalbewerking.

\section{Implicaties voor arbeidsinhoud en competentiebehoeften}

Nanotechnologie vraagt om interdisciplinaire kennis van natuurwetenschappen, en afhankelijk van de branche of sector waarin wordt gewerkt, vaardigheden en kennis van vakgebieden als fotonica, optica, lasertechnologie of galvaniseren (Invernizzi, 2011). De literatuur over nanotechnologie beschrijft tot nu toe voornamelijk de impact ervan op de gevraagde kennis en vaardigheden van hoogopgeleid personeel. Nanotech-fabricatie vraagt om kennis van fabricatie van nano-structuren, nanoschaal-instrumenten en apparaten en synthese van nanomaterialen, zoals sol-gel technieken (bekleding van materialen), lithografie technieken (een techniek om kleine structuren aan te maken voor bijvoorbeeld een printplaat of geïntegreerde schakeling), kennis van self-assemblage, en laagop-laag-technieken. Om te kunnen werken aan Research \& Development, productie en kwaliteitscontrole met en van nano-structuren moeten medewerkers de atomische structuur van materialen kunnen bepalen aan de hand van beschikbare meetinstrumenten. Dit betekent dat zij bijvoorbeeld moeten kunnen werken met een elektronenmicroscoop, atomische-krachten-microscoop, een transmissieelektronenmicroscoop of röntgenapparaten (Invernizzi, 2011).

Werken met nanotechnologie betekent ook dat er andere veiligheidssituaties ontstaan. Werknemers moeten bijvoorbeeld leren werken met nieuwe materialen en de veiligheidsrisico's die daaraan verbonden zijn. Daaronder valt ook dat zij moeten kunnen werken in zogenoemde 'clean rooms' (Invernizzi, 2011). Clean rooms zijn afgeschermde, steriele kamers, ontworpen om in productie- of bewerkingsprocessen besmetting met stof of vezels of andere moleculen in de lucht tegen te gaan. Dit vereist ook dat er meer 'clean room operators' worden aangenomen (Gijsbers et al., 2016).

Een andere ontwikkeling die gaande is in de nanotechnologie, is die van de selfreporting materials, waarbij materialen zelfstandig een verandering van eigenschappen laten zien in geval van kwaliteitsverlies. Onderhoudstechnici aan de productielijn moeten in de toekomst kunnen herkennen wanneer en op welke 
wijze ze moeten ingrijpen bij kwaliteitsverlies van deze self-reporting materialen (Dworschak \& Zaiser, 2014).

\section{Samenvatting en conclusie}

De vraag die centraal staat in dit onderzoek, is: welke kennis is er over de impact van relevante technologische ontwikkelingen op arbeidsinhoud en competentiebehoeften in technische beroepen in de industrie? Het onderzoek betreft een literatuuronderzoek, verrijkt met voorbeelden uit de industriepraktijk. Het antwoord op de onderzoeksvraag is van groot belang om een zo concreet mogelijk beeld te krijgen van belangrijke actuele verschuivingen in de arbeidsinhoud en competentiebehoeften. Dat inzicht is van belang voor zowel werkgevers als werknemers van nu en straks om optimaal te kunnen anticiperen op die verschuivingen door toekomstgerichte deelname aan opleiding en ontwikkeling. Het helpt de industriesectoren om, zo mogelijk gezamenlijk, een toekomstbestendig scholings- en arbeidsmarktbeleid vorm te geven en om te komen tot onderbouwde collectieve afspraken over de verdere ontwikkeling van zowel de sector als die van huidige en toekomstige generaties werknemers.

In algemene zin trekken we allereerst de conclusie dat bruikbare literatuur schaars is. Literatuur is schaars in de zin dat er veel bekend is over technologische ontwikkelingen zelf, maar dat er via Scopus en Google Scholar weinig artikelen ontsloten kunnen worden over de concrete impact van verschillende technologieën op de arbeidsinhoud en daaraan gerelateerde competentiebehoeften van technische beroepen in de industrie. Het is blijkbaar (nog) niet vanzelfsprekend om bij het ontwikkelen van nieuwe technologieën en het onderzoeken van prestaties van nieuwe technische systemen ook de gevolgen voor de arbeidsinhoud (taken, taakverdeling) en de daaruit voortvloeiende competentiebehoeften mee te nemen. Dat is een belangrijke conclusie, want juist de inbedding van nieuwe technologieën in werkprocessen is van groot belang voor de effectiviteit van de organisaties als geheel (Oeij et al., 2016; Volberda, Jansen, Tempelaar, \& Heij, 2011).

De inhoudelijke inzichten die we in de schaarse literatuur hebben kunnen vinden, zijn gepresenteerd in Tabel 1.

De literatuur over de impact van robotisering en co-bots op taken en competenties heeft specifieke aandacht voor zowel operators als programmeurs en onderhoudstechnici. Operators gaan minder handmatig en routinematig werk doen en worden minder fysiek belast. Daarvoor in de plaats moeten ze de robots bedienen, het proces monitoren en logistieke handelingen verrichten. Daarvoor hebben ze basiskennis en vaardigheden nodig rondom het (samen)werken met, en (eenvoudig) programmeren van, robots en cobots. Ook moeten ze eenvoudige storingen kunnen oplossen en is basiskennis nodig op het gebied van veiligheid en arbo. De programmeurs en onderhoudstechnici voeren complexere taken uit op het gebied van programmeren, onderhoud en storingsanalyse. Daarvoor hebben ze meer diepgaande kennis nodig over de werking en eigenschappen van de robots en cobots en de softwarematige aansturing. Ook spelen ze een rol in het optimaliseren van werkprocessen, waarvoor procesinzicht van belang is. 


\section{Tabel 1 Overzicht van inhoudelijke bevindingen}

Taken

Competenties

\section{Robotisering en co-botisering}

Operators

- (Samen)werken met robots

- Toezichthouden op door robots uitgevoerde productieprocessen (storingen, veiligheid)

- Logistieke handelingen (bijv. voor het open afspannen van materialen)

- Minder simpele repetitieve taken

- Minder fysieke belasting

Programmeurs en onderhoudstechnici

- Programmering van robots

- Onderhoud aan robots, storingen oplossen

- Bijdragen aan de optimalisering van het productie- en logistieke proces
- Basisvaardigheden bediening van robots

- (Basis)kennis programmeren van eenvoudige robots

- Kennis van processen, (eenvoudige) storingen

- Kennis van wetgeving op het gebied van arbo en veiligheid, ergonomie

- Technische kennis over de werking van robots

- Vaardigheden m.b.t. de programmering van (geavanceerde) robots, kwaliteitscontrole en onderhoud van robots, storingsanalyse

- Vaardigheden m.b.t. softwarematige besturing van machines en robots en ontwerpen van producten (computer-aided design/computeraided manufacturing)

\section{Internet of Things en cyber-physical systems}

- Bediening van productiestraten (i.p.v. indivi- • Vaardigheden m.b.t. parametriseren, plannen duele machines en robots)

- Door complexere productieprocessen ontstaan er complexe taken voor hoger opgeleid technisch personeel

- Uitvoeren complexere storingsanalyse (meer disciplines betrokken), ondersteund door systemen zelf, en deels op afstand

- Minder simpele repetitieve taken (handmatige bediening individuele machines of invoer data)

\section{D-printen / 'additive manufacturing'}

- Bediening 3D-printer - Bediening vergt basiskennis

- Ontwikkelen van producten in 3D-CAD, - Diepgaande programmeer- en IT-vaardiginclusief materiaal en proceskeuze

- Tekeningen interpreteren en controleren - Diepgaande engineeringsvaardigheden op bijvoorbeeld maatvoering, vorm en plaats, tolerantie en maakbaarheid, voordat tot productie wordt overgegaan

\section{Nanotechnologie / nieuwe materialen}

- Research \& Development

- Productie en kwaliteitscontrole met en van nano-structuren

- De atomische structuur van materialen bepalen

- Veiligheid kunnen borgen in bijv. 'clean rooms' heden

- Combinatie van kennis van IT, elektromechanische systemen, sensoren, radio's en andere transmissiesystemen

Systeemdenken en procesdenken (hele productiestraten kunnen overzien)

- Systematisch analyseren en probleemoplossend vermogen

- Interpretatie en gebruik van data

- Communicatievaardigheden om met verschillende experts en op afstand te kunnen adviseren

- Technisch-inhoudelijke kennis van mogelijkheden/toepassingen, printtechnieken, printbare materialen, mogelijkheden om 3Dscanning en 3D-printing te combineren

- Interdisciplinaire kennis van natuurwetenschappen

- Vaardigheden en kennis van vakgebieden als fotonica, optica, lasertechnologie of galvaniseren (afhankelijk van sector)

- Kennis van fabricatie van nano-structuren, nanoschaal-instrumenten en -apparaten en synthese van nano-materialen

- Kennis van self-assemblage, en laag-op-laagtechnieken

- Kennis van specifieke veiligheidsrisico's 
Via Internet of Things worden onder meer verschillende robots, co-bots en andere machines gekoppeld, en een deel van de verandering van taken en vaardigheden ligt in het verlengde van de veranderingen door de introductie van robots. Productieprocessen worden complexer, operators zullen in plaats van individuele machines en robots hele productiestraten bedienen en moeten overzien. Procesinzicht en systeemdenken worden daarmee van groter belang. Ook storingsanalyse wordt complexer en zal daarnaast ook op afstand moeten plaatsvinden. Door het koppelen van verschillende systemen zijn ook meer verschillende expertises nodig, waardoor (interdisciplinaire) samenwerking en communicatie belangrijker worden. In de laatste plaats moeten de gegenereerde data kunnen worden geïnterpreteerd en gebruikt.

Vooralsnog wijst de literatuur over 3D-printing vooral op de toevoeging van nieuwe werkzaamheden die samengaan met 3D-printing. Net als bij de robots en co-bots gaat het om het bedienen, programmeren en ontwerpen. De bediening is vaak eenvoudig werk en het programmeren en ontwerpen is vaak complexer werk. Bij het ontwerpen zijn kennis en vaardigheden van de applicaties (3DCAD) van belang, maar is ook kennis nodig van de beschikbare materialen en het printproces.

De informatie die beschikbaar is over de impact van nanotechnologie op taken en competenties, richt zich met name op hoger opgeleid personeel. Er moet interdisciplinaire kennis zijn van natuurwetenschappen, en sectorspecifieke kennis. Het vereist kennis van (de fabricage van) nanostructuren en men moet kunnen werken met specifieke apparatuur. Ook spelen er specifieke veiligheidsrisico's en moeten werknemers leren werken in zogenaamde 'clean rooms'.

Het onderzoek was erop gericht om zo concreet en specifiek mogelijk te kunnen vaststellen welke veranderingen in arbeidsinhoud en competentiebehoeften verwacht worden zodat werkgevers, werknemers, onderwijsinstanties en andere stakeholders daar concrete interventies voor konden ontwikkelen. Wij wilden de overkoepelende abstracte inzichten over verschuivingen in arbeidsinhoud en competenties zoals beschreven in rapporten van de SER (2016), WRR (2015) en het Rathenau Instituut (2015) concretiseren en specifiek maken voor verschillende opleidingsniveaus en functies in de technische sector. In de literatuur wordt echter nauwelijks tot geen onderscheid gemaakt naar specifieke functies, beroepen of opleidingsniveaus. Voor opleiders en sociale partners (en A\&O-fondsen) die nieuwe competentiebehoeften moeten doorvertalen naar concrete opleidingsprogramma's, is dat onderscheid echter wel van groot belang.

Verder is het van belang op te merken dat lerend vermogen een competentie is die in de beschikbare literatuur over specifieke technologische ontwikkelingen in de industrie niet altijd expliciet wordt benoemd, maar op de achtergrond wel een belangrijke rol speelt. Ook in de algemene literatuur over de impact op de arbeidsmarkt als geheel zien we deze competentie benoemd (zie bijvoorbeeld SER, 2016). De introductie van een nieuwe robot vraagt van operators dat ze ermee leren werken. Uiteraard worden medewerkers vaak ondersteund door cursussen, bijvoorbeeld vanuit de leverancier, maar ze moeten de informatie kunnen verwerken en zich de nieuwe bedieningsapparatuur zo snel mogelijk eigen kunnen maken. Het lerend vermogen is een meer abstracte competentie die echter wel ontwikkeld kan worden door bijvoorbeeld gevarieerde en uitdagende takenpakketten en het zo laag mogelijk in de organisatie beleggen van 
bevoegdheden en verantwoordelijkheden, zodat leren een standaardonderdeel vormt van het werk en deze vaardigheid zo wordt ontwikkeld (zie bijv. Karasek \& Theorell, 1990; De Sitter, Den Hertog, \& Dankbaar, 1997; Dhondt, Pot, \& Kraan, 2014).

De eerder gepresenteerde inhoudelijke inzichten met betrekking tot de vraag wat relevante technologieën betekenen voor de competentiebehoefte van technisch personeel zijn ons inziens slechts een vertrekpunt voor de technische sectoren en de wetenschap. Het is, zoals gezegd, van cruciaal belang dat er inzicht is in de concrete impact van technologieën op de competentiebehoefte van specifieke functies met bijbehorende opleidingsniveaus. Dat inzicht is er op dit moment onvoldoende en daardoor kunnen relevante partijen zoals sociale partners en opleidingsinstellingen niet tijdig actie ondernemen voor de ontwikkeling van relevante competenties via opleidingsprogramma's of andere interventies. Om deze impact wel voldoende inzichtelijk te maken is een nauwe samenwerking tussen wetenschap en praktijk noodzakelijk. Onze aanbevelingen richten zich daarom op zowel de wetenschap als de sociale partners in de technische sectoren. Onze belangrijkste aanbeveling is dat de technische sector en de wetenschap (in samenwerking met onderwijs en overheid) substantieel zouden moeten investeren in een breed en gezamenlijk onderzoeksprogramma waarin de vraag centraal staat: 'Wat is precies de nieuwe competentiebehoefte voor technische beroepen?' De uitdaging is om de overkoepelde abstracte inzichten uit studies van het Rathenau Instituut (2015), de WRR (2015) en de SER (2016) over de impact van technologie op taken en competenties door te vertalen naar specifieke functies en taken in de technische sectoren. Onze aanbeveling ligt in het verlengde van het advies van de SER, waarin sectorale impact assessments en monitoring van de impact van technologie een belangrijke rol spelen. Alleen op die manier worden de abstracte '21st century skills' concreet en toegespitst op specifieke taken en functies. Alleen op die manier kunnen sociale partners, overheden, bedrijven en onderwijs gezamenlijk adequate interventies ontwikkelen om te werken aan het toekomstbestendig maken van bedrijven en werkenden. Een tweede aanbeveling is, in het verlengde van het onderzoek naar precieze duiding van de nieuwe en te verwachten competentiebehoeften, om als sector en wetenschap de impact van technologieën op arbeidsinhoud en competentiebehoefte integraal mee te nemen bij het ontwikkelen van nieuwe technologieën. Door in een vroeg stadium rekening te houden met deze impact kan de technologie beter afgestemd worden op de toekomstige gebruikers en worden inzichten over benodigde competenties vroegtijdig beschikbaar voor gebruikers, zodat die zich adequate kunnen voorbereiden. In de 'Fieldlabs Smart Industry' wordt veel geïnvesteerd in de ontwikkeling van nieuwe technologieën, maar de gevolgen voor taken, benodigde competenties en de ontwikkeling daarvan krijgen slechts in hele beperkte mate aandacht.

In de laatste plaats adviseren we de wetenschap en de sector om gezamenlijk te investeren in onderzoek naar de effectiviteit van informele en formele leertrajecten en de relatie tussen beide. Lerend vermogen is een centrale competentie bij het werken met nieuwe technologieën en met name voor werkenden in technische beroepen is leren door te doen en te werken een belangrijke manier om nieuwe competenties te ontwikkelen. Experimenten met deze vormen van leren liggen derhalve het meest voor de hand. We adviseren om ook met deze 
experimenten en onderzoeken naar skillsontwikkeling zoveel mogelijk aan te sluiten bij bestaande initiatieven, zoals de bestaande 'Fieldlabs Smart Industry'. Die Fieldlabs zijn meestal opgezet rondom bepaalde technologische ontwikkelingen en kunnen zeer gebaat zijn bij experimenten met sociale innovatie en het aanleren van nieuwe skills en competenties.

\section{Noot}

1 Dworschak \& Zaiser (2014, p. 346) doelen hier op personeel met 'medium-level qualifications'. Hieronder vallen voornamelijk werknemers die een opleiding hebben gevolgd in een nationaal erkend beroep of vak, evenals werknemers die een opleiding hebben gevolgd tot vakman of technicus.

\section{Literatuur}

Abelshausen, T., Albertijn, M., \& Hoefnagels, K. (2014). Toekomstige competentievereisten in de elektrotechnische sector: Competentiemeting in het kader van het Vlaams Arbeidsmarktonderzoek voor de Toekomst in de elektrotechnische sector. Antwerpen: Tempera.

Achtenhagen, C., \& Zeller, B. (2013). The future skill requirements engendered by the 'Internet of Things' in industrial production. In FreQueNz (Ed.), Future skills needed for the Internet of Things in industrial production. Summary of study findings (pp. 0508). FreQueNz.

A+O Metalektro. (2017). Door te innoveren word je vanzelf ook een interessante werkgever. Verkregen van: https://ao-metalektro.nl/over-de-sector/best-practices/557-door-teinnoveren-word-je-vanzelf-ook-een-interessante-werkgever

Arntz, M., Gregory, T., \& Zierahn, U. (2016). The risk of automation for jobs in OECD countries: A comparative analysis. OECD Social, Employment and Migration Working Papers, No. 189. Paris: OECD Publishing. http://dx.doi.org/10.1787/5jlz9h56dvq7-en

Bezemer, R., Kuindersma, P., \& Mulder, G. (2016). BIA UNETO-VNI 3D printen: De installatiesector als maakindustrie. Delft: TNO.

Bezemer, R.A., \& Smit, C.J.C. (2017). BIA UNETO-VNI Robotisering: Een sprong vooruit. Delft: TNO.

Brynjolfsson, E., \& McAfee, A. (2014). The second machine age. New York/London: Norton.

Corporaal, S., Alons, M., \& Vos, M. (2015). Werken in de nieuwe industriële realiteit: Een verkennend onderzoek naar de verwachtingen van werkgevers over jonge technici. Verkregen van: http://www.arbeidsconferentie.nl/uploads/submission/document_1/97/2015__Corporaal_et_al_-_werken_in_de_nieuwe_industriele_realiteit_MvR.pdf.

Cörvers, F., De Hoon, M., \& Van den Tillart, H. (2017). De macrodoelmatigheid van nu en de MEI medewerker van morgen. Nijmegen/Maastricht: ITS \& ROA.

De Graaf-Zijl, M., Josten, E., Boeters, S., Eggink, E., Bolhaar, J., Ooms, I., Den Ouden, A., \& Woittiez, I. (2015). De onderkant van de arbeidsmarkt in 2025. Den Haag: CPB.

Deloitte. (2014). De impact van automatisering op de Nederlandse arbeidsmarkt: Een gedegen verkenning op basis van Data Analytics. Amstelveen: Deloitte.

De Sitter, L.U., Den Hertog, J.F., \& Dankbaar, B. (1997). From complex organizations with simple jobs to simple organizations with complex jobs. Human Relations, 50(5), 497-534.

De Vos, A., \& Gielens, T. (2016). The future of jobs in chemistry and life sciences - sectoranalyse chemische industrie, kunststoffen en life sciences in Vlaanderen. Antwerpen: Antwerp Management School.

Dhondt, S., Pot, F.D., \& Kraan, K.O. (2014). The importance of organizational level decision latitude for well-being and organizational commitment. Team Performance Management: An International Journal, 20(7/8), 307-327. 
Dworschak, B., \& Zaiser, H. (2014). Competences for cyber-physical systems in manufacturing - first findings and scenarios. Procedia CIRP, 25, 345-350.

Dworschak, B., Zaiser, H., \& Achtenhagen, C. (2013). The 'Internet of Things' and 'industrial production' as part of the early identification initiative of the German Federal Ministry of Education and Research (BMBF). In FreQueNz (Ed.), Future skills needed for the Internet of Things in industrial production. Summary of study findings (pp. 02-04). FreQueNz.

Folmer, W. (2013). De metaalmedewerker van morgen. Hazerswoude-dorp: Opleidings- en ontwikkelingsfonds Metaalbewerking.

Frey, C.B., \& Osborne, M.A. (2013). The future of employment: How susceptible are jobs to computerisation? Paper. Oxford, UK: Oxford Martin School, Oxford University.

Gijsbers, G.W., Van den Broek, T.A., Esmeijer, J., \& Sanders, J.M.A.F. (2016). Smart skills voor smart industry : Hoe werk verandert in de fabriek van de toekomst. Delft: TNO.

Goos, M., Manning, A., \& Salomons, A. (2014). Explaining job polarization: Routinebiased technological change and offshoring. AER, 104(8), 2509-2526.

Hirsch-Kreinsen, H. (2014). Smart production systems: A new type of industrial process innovation. Paper presented at DRUID Society Conference 2014, CBS, Copenhagen, June 16-18.

Hooftman, W.E., Mars, G.M.J., Janssen, B.J.M., De Vroome, E.M.M., \& Van den Bossche, S.N.J. (2015). Nationale Enquête Arbeidsomstandigheden 2014 (NEA 2014): Methodologie en globale resultaten. Leiden/Heerlen: TNO/CBS.

International Federation of Robotics (IFR). (2017). How robots conquer industry worldwide. IFR Press Conference, 27 September 2017, Frankfurt.

ING Economisch Bureau (2016). Mens en Machine in de flexbranche: Hoe de flexbranche technologie als kans kan benutten. Amsterdam: ING.

Invernizzi, N. (2011). Nanotechnology between the lab and the shop floor: What are the effects on labor? Journal of Nanopart Research, 13, 2249-2268.

Karasek, R., \& Theorell. T. (1990). Healthy work: Stress, productivity, and the reconstruction of working life. New York: Basic Books.

KPN. (2017). HR Groep: slimme borden. Verkregen van: https://www.kpn.com/zakelijk/ thedigitaldutch/klantcase/hr-groep-slimme-borden.htm

Levy, F., \& Murnane, R.J. (2013). Dancing with robots: Human skills for computerized work. Washington: Third Way.

Marks, F. \& Penris, J. (2013). Op weg naar zelfsturende productie: Maatwerk als massaproduct in de industrie. Mechatronica en Machinebouw 6. Verkregen van: https:// mechatronicamachinebouw.nl/fileadmin/uploads_redactie_mm/Magazines/Mechatronica_Machinebouw-06-2013-72dpi.pdf

Moniz, A.B., \& Krings, B.J. (2016). Robots working with humans or humans working with robots? Search for social dimensions in new human-robot interaction in industry. Societies, 6(23). doi:10.3390/soc6030023

Oeij, P.R.A., Van der Torre, W., Van de Ven, H.A., Sanders, J.M.A.F., \& Van der Zee, F.A. (2016). Nieuwe technologie en werk: Onderzoek en beleidsadvies voor UWV. Leiden: TNO.

Sociaal-Economische Raad (SER). (2016). Verkenning en werkagenda digitalisering; Mens en technologie: samen aan het werk. Den Haag: Sociaal-Economische Raad.

Skevi, A., Szigeti, H., Perini, S., Fradinho Duarte de Oliveira, M., Taisch, M., \& Kiritsis, D. (2014). Current skills gap in manufacturing: Towards a new skills framework for factories of the future. IFIP Advances in Information and Communication Technology, 438. doi:10.1007/978-3-662-44739-0_22

Smits, W., \& De Vries, J. (2015). Toenemende polarisatie op de Nederlandse arbeidsmarkt. ESB, 100(4701), 24-25.

Van den Berge, W., \& Ter Weel, B. (2015). Baanpolarisatie in Nederland. CPB Policy Brief 2015/13. Den Haag: CPB.

Van Dijk, V. (2017). Praktijkvoorbeeld robotlassen bij Hapert Aanhangwagens.

Van Est, R., \& Kool, L. (Eds.). (2015). Werken aan de robotsamenleving: Visies en inzichten uit de wetenschap over de relatie technologie en werkgelegenheid. Den Haag: Rathenau Instituut. 
Vermeulen, H., Warmerdam, J., Elfering, S., Schellingerhout, R., De Wit, W., Van de Wetering, E., Rossen, L., \& Van Rens, C. (2014). Trends en ontwikkelingen in de technische installatiebranche 2014: Bedrijvigheid, arbeidsmarkt en beroepsopleiding in de periode tot 2020. Nijmegen: ITS.

Volberda, H.W. Jansen, J.J.P., Tempelaar, M.P., \& Heij, C.V. (2011). Monitoren van sociale innovatie: Slimmer werken, dynamisch managen en flexibel organiseren. Tijdschrift voor HRM, 14, 85-110.

Wetenschappelijke Raad voor het Regeringsbeleid (WRR). (2015). De robot de baas: De toekomst van werk in het tweede machinetijdperk. Den Haag: Wetenschappelijke Raad voor het Regeringsbeleid. 